DOI https://doi.org/10.30525/978-9934-26-111-4-24

\title{
ОСОБЛИВОСТІ ЗБЕРЕЖЕННЯ ПРИРОДНИХ ВОД ДНІПРОВСЬКОГО БАСЕЙНУ УКРАЇНИ У КОНТЕКСТІ АПРОКСИМАЦЇ̈ ЄВРОПЕЙСЬКИХ ДИРЕКТИВ
}

\author{
Строкаль В. П. \\ кандидат педагогічних наук, \\ дочент кафедри екології агросфери та екологічного контролю \\ Національний університет біоресурсів і природокористування Украӥни \\ м. Київ, Україна
}

Збереження вод Дніпровського басейну України $\epsilon$ важливим питанням на всіх рівнях організації та здійснення водної політики держави $[1,16]$. Зокрема основною підставою даного твердження $€$ те, що 48\% території України займає басейн Дніпра, охоплює 19 областей України [17] та до 75\% забезпечує населення держави питною водою [1]. Після підписання Угоди «Про Асоціацію України-СС», починаючи з 2017 року (з моменту набуття чинності) в державі почали відбуватися зміни у водному законодавстві [2]. Варта зазначити, що однією із вимог Угоди було проведення процедури апроксимації, яка означала наближення нормативів та процедур національного законодавства до вимог Свропейських Директив [4]. Зокрема в Україні проведено імплементацію Свропейських Директив 3 наступними результатами [2]:

1. Водна рамкова директива СС (Директива 2000/60/СС «Про встановлення рамок діяльності Співтовариства в галузі водної політики», https://zakon.rada.gov.ua/laws/show/994_962) - сприяла формуванню структури охорони внутрішніх вод, перехідних вод, прибережних вод і грунтових вод [6, 7, 9-12].

2. Рамкова Директива про морську стратегію (Директива 2008/56/СС про встановлення рамок діяльності Співтовариства у сфері політики 3 морського середовища, https://menr.gov.ua/files/docs/2008 \%2056\%20\%D0\%84\%D0\%A1.pdf) - сприяла розробці стратегічних напрямків екологічної політики щодо охорони та відтворення довкілля морів Україна, що розташовані у басейнах Чорного, Азовського та Балтійського морів [14].

3. Паводкова директива (Директива 2007/60/СС «Про оцінку та управління ризиками затоплення», https://zakon.rada.gov.ua/ laws/show/994_b29) - передбачала підготовку планів управління басейнами річок та проведення консультації 3 громадськістю, 
удосконалення законодавства України щодо оцінки та управління ризиками затоплення внаслідок паводків, проведення попередньої оцінки ризиків затоплення, підготовка карт загроз та ризиків затоплення [5].

4. Директива про питну воду (Директива СС 98/83/ЄС про якість води, призначеної для споживання людиною, https://zakon.rada.gov.ua/laws/show/994_963) - встановила стандарти якості води (48 мікробіологічних та хімічних показників) для усіх систем водопостачання, що обслуговують понад 50 осіб або постачають більше $10 \mathrm{~m}^{3} /$ добу $[8,11,18]$.

5. Нітратна Директива (Директива Ради 91/676/СЕС стосовно охорони вод від забруднення, спричиненого нітратами 3 сільськогосподарських джерел, https://menr.gov.ua/files/docs/91\%20676\% $20 \% \mathrm{D} 0 \% 84 \% \mathrm{D} 0 \% 95 \% \mathrm{D} 0 \% \mathrm{~A} 1 . \mathrm{pdf})$ - сприяла розробці та затвердженню методики визначення зон, вразливих до (накопичення) нітратів [3].

Слід зазначити, що якість води Дніпровського басейну України 3 роками все погіршується [18]. За рахунок збільшення виробництва птиці у державі [1], відсутністю централізованого водопостачання та водовідведення у сільських місцевостях [2], а також внаслідок скидів неочищених вод від житлово-комунальних та промислових господарств у водойми [15], основними чинниками забруднення природних вод Дніпровського басейну вбачають інтенсифікацію процесів евтрофікації водойм, пригнічення біоти водної екосистеми внаслідок надходження значної кількості сполук азоту та фосфатів (вплив горизонтальної та вертикальної міграції), що у свою чергу призводить до погіршення якості природної води по відношенню до споживання людиною, риборозведення та рекреаційних цілей [2].

3 огляду на вище викладені фактори антропогенного впливу на стан водної екосистеми природних вод, процес апроксимація є важливим та необхідним для врегулювання основних нормативів, обгрунтування специфіки збереження природних вод та подолання низки негативних факторів, які впливають на стан води.

\section{Література:}

1. Strokal V.P., Kovpak A.V. THE BASIN APPROACH FOR WATER RESOURCES MANAGEMENT IN UKRAINE: THE SWOT ANALYSIS / Scientific journal «Biological systems: theory and innovation», Том 11, № 4 (2020). http://journals.nubip.edu.ua/ index.php/Biologiya/issue/view/598, DOI: http://dx.doi.org/10.31548/ biologiya2020.04.004 
2. Vita Strokal (2021). Transboundary rivers of Ukraine: perspectives for sustainable development and clean water, Journal of Integrative Environmental Sciences, 18:1, 67-87, DOI: 10.1080/1943815X.2021. 1930058 , https://www.tandfonline.com/doi/pdf/10.1080/1943815X. 2021.1930058

3. Директива Ради 91/676/СЕС стосовно охорони вод від забруднення, спричиненого нітратами з сільськогосподарських джерел: https://menr.gov.ua/files/docs/91\%20676\%20\%D0\%84\%D0\%95\%D0\%A1. pdf

4. Імплементація принципів інтегрованого управління в системі галузевих підкомплексів водного господарства / Г.С. Штогрин // Науковий журнал «Економіка природокористування та охорони навколишнього середовища». 2018. Випуск 19. С. 413-420. Режим доступу: http://www.market-infr.od.ua/journals/2018/19_2018_ukr/70.pdf

5. Наказ Міністерства внутрішніх справ України «Про затвердження Методики розроблення карт загроз і ризиків затоплення» № 153 від 28.02.2018 p. - Режим доступу: https://zakon.rada.gov.ua/laws/show/ z0350-18\#Text

6. Наказ Міністерства екології та природних ресурсів (нині Міністерство енергетики та захисту довкілля) «Про затвердження типового положення про басейнові ради» від 26.01.2017 № 23: https://zakon.rada.gov.ua/laws/show/z0231-17

7. Наказ Міністерства екології та природних ресурсів (нині Міністерство енергетики та захисту довкілля) «Про виділення суббасейнів та водогосподарських ділянок у межах встановлених районів річкових басейнів» від 26.01.2017 № 25: https://zakon.rada.gov.ua/laws/show/z0208-17

8. Наказ Міністерства екології та природних ресурсів (нині Міністерство енергетики та захисту довкілля) «Про затвердження Переліку забруднюючих речовин для визначення хімічного стану масивів поверхневих і підземних вод та екологічного потенціалу штучного або істотно зміненого масиву поверхневих вод» від 06.02.2017 № 45: https://zakon.rada.gov.ua/laws/show/z0235-17

9. Наказ Міністерства екології та природних ресурсів (нині Міністерство енергетики та захисту довкілля) «Про затвердження Меж районів річкових басейнів, суббасейнів та водогосподарських ділянок» від 03.03.2017 № 103: https://zakon.rada.gov.ua/laws/show/z0421-17

10. Наказ Міністерства екології та природних ресурсів (нині Міністерство енергетики та захисту довкілля) «Про затвердження 
Порядку розроблення водогосподарських балансів» від 26.01.2017 № 26: https://zakon.rada.gov.ua/laws/show/z0232-17

11. Наказ Міністерства екології та природних ресурсів України «Про затвердження Методики віднесення масиву поверхневих вод до одного 3 класів екологічного та хімічного станів масиву поверхневих вод, а також віднесення штучного або істотно зміненого масиву поверхневих вод до одного з класів екологічного потенціалу штучного або істотно зміненого масиву поверхневих вод» № 5 від 14.01.2019 р.: https://zakon.rada.gov.ua/laws/show/z0127-19\#Text

12. Постанова Кабінету Міністрів України «Про затвердження Порядку здійснення державного моніторингу вод» від 19.09.2018 р. № 758: https://zakon.rada.gov.ua/laws/show/758-2018-\%D0\%BF

13. Постанова Кабінету Міністрів України «Про затвердження Порядку розроблення плану управління річковим басейном» від 18.05.2017 p. № 336: https://zakon.rada.gov.ua/laws/show/336-2017$\% \mathrm{D} 0 \% \mathrm{BF}$

14. Розпорядження Кабінету Міністрів України «Про схвалення Стратегії імплементації положень директив та регламентів Свропейського Союзу у сфері міжнародного морського та внутрішнього водного транспорту («дорожньої карти»)» від 11 жовтня 2017 р. № 747-р.: https://zakon.rada.gov.ua/laws/show/747-2017-\%D1\%80\#Text

15. Строкаль В.П. Антропогенне навантаження на стан водних та земельних ресурсів: проблеми локальних територій України / Науковопрактичний журнал «Збалансоване природокористування», Інститут агроекології і природокористування Національної академії аграрних наук України, Вид-во: ТОВ «Екоінвестком», 2020. №2(2020). С. 119128 DOI: https://doi.org/10.33730/2310-4678.2.2020.208822

16. Строкаль В.П., Ковпак А.В., Курочка Т.Л. Застосування інноваційних технологій для зменшення антропогенного навантаження на стан водної екосистеми / [III Міжнародна науково-практична конференція «Екологічні проблеми навколишнього середовища та раціонального природокористування в контексті сталого розвитку»] : збірник матеріалів (22-23 жовтня 2020, м. Херсон, Україна). Херсон: «ОЛДІ-ПЛЮС», 2020. С. 912-915

17. Технічний звіт: опис характеристик району басейну річки Дніпро / Проєкт «Водна ініціатива Європейського Союзу Плюс для країн Східного Партнерства: Результати 2 і 3 (ENI/2016/372-403)», 2020. - 40 c.: https://euwipluseast.eu/images/2020/01/PDF/EUWI_UA_ Dnipro_Characteristic_Summary_UA_2020.pdf 
18. Цвєткова А., Закорчевна Н. Протокол про воду і здоров'я як інструмент водної безпеки. ECOBUSINESS. Екологія підприємства. 2020. № 2. C. 14-18.

DOI https://doi.org/10.30525/978-9934-26-111-4-25

\section{ЕКОЛОГІЧНЕ НАВЧАННЯ І ВИХОВАННЯ ЯК СКЛАДОВА ЕВРОПЕЙСЬКИХ СТАНДАРТІВ ПРИ НАВЧАННІ ПРОВІЗОРІВ}

Хмельникова Л. І.

кандидат хімічних наук, доиент кафедри біохімї та медичної хімї

Дніпровський державний медичний університет

Більчук В. С.

кандидат біологічних наук, викладач кафедри біохімї та медичної хімії Дніпровський державний медичний університет

\section{Слссарчук В. Ю.}

кандидат біологічних наук,

доцент кафедри загальної та клінічної фармациї Дніпровський державний медичний університет м. Дніпро, Україна

В сучасних умовах в результаті стрімкого розвитку промислової індустрії і величезного впливу антропогенного чинника на навколишнє середовище особливо гостро постає питання його охорони, підтримки еволюційно сформованої рівноваги в природі, раціонального використання природних ресурсів. Гармонійна взаємодія суспільства і природи буде тільки в тому випадку, коли наука, техніка і освіта будуть сприяти формуванню нових моральних критеріїв, спрямованих на усвідомлення особистості себе, як активної частини природи, єдності з нею.

Проблема охорони навколишнього середовища переросла в глобальну екологічну проблему, покликану врятувати людство від загрози загального і незворотного забруднення довкілля. Загрозливих масштабів досягло хімічне забруднення не тільки повітряного басейну, а й грунту, річок. Все це веде до різкого зростання захворюваності населення. 